\title{
Evaluasi Penerapan Standar Pelayanan Kefarmasian di Puskesmas Tanjung Karang
}

\author{
Nur Oktaviani ${ }^{\text {a, }}$ 1* $^{*}$ \\ ${ }^{a}$ Universitas Nadhlatul Wathan Mataram, Mataram, Nusa Tenggara Barat, 83 I I5 \\ ${ }^{1}$ nuroktaviani8485@gmail.com* \\ *korespondensi penulis
}

INFO ARTIKEL
Diterima :
22-I2-2020
Disetujui :
04-OI-202I

Kata kunci:

Evaluasi;

Pelayanan Kefarmasian; Puskesmas Tanjung Karang.

\section{Keywords:}

Evaluation;

Pharmaceutical Services; Puskesmas Tanjung Karang.
ABSTRAK

Pelayanan kefarmasian di puskesmas merupakan satu kesatuan yang tidak terpisahkan dari pelaksanaan upaya kesehatan yang berperan penting dalam meningkatkan mutu pelayanan kesehatan bagi masyarakat, khususnya di bidang kefarmasian Penelitian ini bertujuan untuk mengetahui evaluasi penerapan standar pelayanan kefarmasian di Puskesmas Tanjung Karang. Penelitian ini termasuk penelitian deskriptif, pengambilan data dengan menggunakan pendekatan cross sectional, instrumen dalam penelitian ini adalah kuesioner yang bersumber dari Peraturan Menteri Kesehatan No 74 Tahun 2016 tentang standar pelayanan kefarmasian di Puskesmas. Responden dalam penelitian ini adalah petugas farmasi dan pasien rawat jalan di puskesmas Tanjung Karang. Hasil penelitian yaitu kegiatan pengelolaan obat dan bahan medis habis pakai sebesar $90 \%$, Peralatan dan fasilitas pendukung sebesar $87,5 \%$, pelayanan informasi obat sebesar $100 \%$, dan sumber daya manusia sebesar 100\%.Yang menunjukkan bahwa evaluasi penerapan standar pelayanan kefarmasian di Puskesmas Tanjung Karang berdasarkan Indikator-Indikator pelayanan farmasi sudah di laksanakan dengan baik dengan nilai rata-rata sebesar 94,37\%.

\section{ABSTRACT}

Pharmaceutical services in health centers are an integral part of the implementation of health efforts that play an important role in improving the quality of health services for the community, especially in the field of pharmacy. This study aims to determine the evaluation of the implementation of pharmaceutical service standards at the Tanjung Karang Puskesmas. This research is a descriptive study, data collection using a cross-sectional approach, the instrument in this study is a questionnaire which is sourced from the Minister of Health Regulation No. 74 of 2016 concerning the standard of pharmaceutical services at Puskesmas. Respondents in this study were pharmacy officers and outpatients at Tanjung Karang Public Health Center. The results of the study were the management of drugs and consumable medical materials by $90 \%$, equipment and supporting facilities at $87.5 \%$, drug information services at 100\%, and human resources at $100 \%$, which showed that the evaluation of the implementation of pharmaceutical service standards at the Puskesmas Tanjung Karang based on indicators of pharmaceutical services has been implemented well with an average value of $94.37 \%$.

This is an open access article under the CC-BY-SA license.

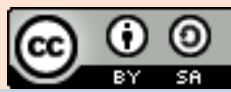

\section{Pendahuluan}

Dalam rangka peningkatan pelayanan kesehatan masyarakat khususnya di bidang kefarmasian sebagai upaya telah di lakukan oleh pemerintah di antaranya menyediakan sarana-sarana pelayanan kesehatan salah satunya adalah puskesmas. Puskesmas merupakan unit organisasi pelayanan kesehatan departemen yang mempunyai misi sebagai pusat pengembangan pelayanan kesehatan secara menyeluruh dan terpadu untuk masyarakat yang tinggal di suatu wilayah kerja tertentu. Puskesmas sebagai salah satu organisasi fungsional pusat pengembangan masyarakat yang memberikan pelayanan promotif (peningkatan), preventive 
(pencegahan), kuratif (pengobatan), rehabilitative (pemulihan kesehatan) (Anonim, 2005).

Seiring berkembangnya ilmu pengetahuan dan tekhnologi dalam bidang kefarmasian serta makin tingginya kesadaran masyarakat dalam meningkatkan kesehatan, maka di tuntut kemampuan dan kecepatan para petugas kefarmasian dalam rangka mengatasi permasalahan yang mungkin timbul dalam pelaksanaan pelayanan kefarmasian kepada masyarakat adapun standar pelayanan kefarmasian yang menjadi tolak ukur yang di pergunakan sebagai pedoman tenaga kefarmasian dalam menyelenggarakan pelayanan kefarmasian dan untuk menjamin mutu pelayanan kefarmasian kepada masyarakat pemerintah telah memperlakukan suatu standar pelayanan kefarmasian di puskesmas dengan di keluarkannya permenkes No 74 tahun 2016 tentang standar pelayanan kefarmasian di puskesmas.

Pelayanan kefarmasian di puskesmas merupakan satu kesatuan yang tidak terpisahkan dari pelaksanaan upaya kesehatan, yang berperan penting dalam meningkatkan mutu pelayanan kesehatan bagi masyarakat. Pelayanan kefarmasian merupakan kegiatan yang terpadu dengan tujuan untuk mengidentifikasi, mencegah dan menyelesaikan masalah obat dan masalah yang berhubungan dengan kesehatan. Tuntutan pasien dan masyarakat akan peningkatan mutu pelayanan kefarmasian, mengharuskan adanya perluasan dari paradigma lama yang berorientasi kepada produk (drug oriented) menjadi paradigma baru yang berorientasi pada pasien (patient oriented) dengan filosofi (pharmaceutical care). Oleh karena itu peneliti melakukan penelitian ini bertujuan untuk mengevaluasi penerapan standar pelayanan kefarmasian yang berorientasi kepada produk (drug oriented) menjadi paradigma baru yang berorientasi pada pasien (patient oriented).

\section{Metode}

\section{Alat}

Alat yang digunakan dalam penelitian ini adalat kuisioner, mencakup tentang kegiatan pengelolaan obat bahan medis habis pakai, peralatan dan fasilitas pendukung, pelayanan informasi obat, dan sumber daya manusia yang ada di puskesmas.

Prosedur

Metode pengolahan data menggunakan data primer yang di lakukan langsung pada responden. Langkah-langkah pengolahan data sebagai berikut:
I. Scoring
Penilaian kuesioner tentang evaluasi penerapan standar pelayanan

2. Tabulating
Setelah data terkumpul kemudian data tersebut di tabulasikan dengan rumus:

$\mathrm{P}=\frac{\mathrm{nA}}{\mathrm{x}} \mathrm{x} 100 \%$

Keterangan :

$\mathrm{P}$ : Persentase

$\mathrm{nA}$ : jumlah jawaban yang sesuai

$\mathrm{x}$ : banyak soal

Dengan Kategori:

Baik $\quad: 81 \%-100 \%$

Cukup : $: 61 \%-80 \%$

Kurang : :20\%-60\%

\section{Hasil dan Pembahasan}

Hasil penelitian berdasarkan data tentang kegiatan pengelolaan obat dan bahan medis habis pakai di puskesmas Tanjung Karang dapat di lihat pada tabel I berikut:

Tabel I. Hasil Indikator Penilaian Pengelolaan Obat dan Bahan Medis habis pakai

\begin{tabular}{llll}
\hline No & $\begin{array}{l}\text { Kegiatan } \\
\text { Pengelolaan Obat } \\
\text { Dan Bahan Medis }\end{array}$ & Jumlah & Hasil \\
& Habis Pakai & \\
\hline I. & Ya & 9 & $90 \%$ \\
2. & Tidak & I & $10 \%$ \\
\hline Total & I0 & I00\% \\
\hline
\end{tabular}

Berdasarkan tabel I dapat di evaluasi dari hasil indikator kuesioner kegiatan Pengelolaan obat dan bahan medis habis pakai bahwa puskesmas tanjung Karang sudah melaksanakan kegiatan pengelolaan obat dan bahan medis habis pakai dengan baik (90\%) namun ada satu jawaban tidak yaitu pendistribusian ke sub unit di lakukan dengan cara pemberian obat sesuai resep yang di terima. Puskesmas Tanjung Karang memakai buku permintaan obat sesuai dengan buku permintaan yang di terima dari masing-masing unit atau depo.

Hasil penelitian berdasarkan data tentang peralatan dan fasilitas pendukung di Puskesmas Tanjung Karang dapat di lihat di tabel 2 berikut:

Tabel 2. Hasil Indikator Penilaian Peralatan Dan Fasilitas Pendukung

\begin{tabular}{|c|c|c|c|c|}
\hline No & $\begin{array}{l}\text { Peralatan } \\
\text { Fasiltas } \\
\text { Pendukung }\end{array}$ & dan & Jumlah & Hasil \\
\hline I. & $\mathrm{Ya}$ & & $\mathrm{I} 4$ & $87,5 \%$ \\
\hline 2. & Tidak & & 2 & $12,5 \%$ \\
\hline Tot: & & & 16 & $100 \%$ \\
\hline
\end{tabular}

Berdasarkan tabel 2 dapat di lihat bahwa peralatan dan fasilitas pendukung di puskesmas Tanjung Karang di pelayanan Farmasi dengan 
kategori Baik (87,5 \%). Dari 16 item peralatan dan fasilitas pendukung masih terdapat kekurangan sebesar 12,5 \% yang di mana Puskesmas Tanjung Karang tidak memiliki blanko salinan resep dan tidak memiliki ruang konseling untuk pasien.

Hasil penelitian berdasarkan Pelayanan Informasi Obat di Puskesmas Tanjung Karang dapat di lihat di tabel 3 berikut:

Tabel 3. Hasil Indikator Penilaian Informasi Obat

\begin{tabular}{llll}
\hline No & $\begin{array}{l}\text { Pelayanan } \\
\text { Informasi } \\
\text { Obat }\end{array}$ & Jumlah & Hasil \\
\hline I. & Ya & 5 & I00\% \\
2. & Tidak & 0 & 0 \\
\hline \multicolumn{2}{l}{ Total } & 5 & $\mathrm{I} 00 \%$ \\
\hline
\end{tabular}

Berdasarkan tabel 3 dari 2 item pertanyaan Pelayanan Informasi Obat di puskesmas Tanjung Karang dapat di laksanakan dengan baik (100\%).

Hasil penelitian berdasarkan Sumber Daya Manusia di Puskesmas Tanjung Karang dapat di lihat di tabel 4 berikut:

Tabel 4. Hasil Indikator Penilaian Sumber Daya Manusia

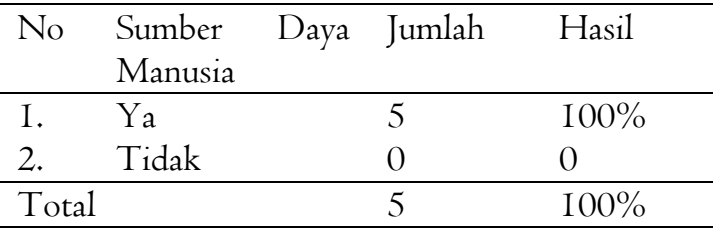

Berdasarkan tabel 4 dapat di gambarkan bahwa Sumber Daya Manusia dari 2 item indikator pertanyaan Puskesmas Tanjung Karang sudah dapat terpenuhi (100\%).

Tabel 5. Jumlah Hasil Persentase Dari Masing

Masing Indikator Pertanyaan Kuesioner

\begin{tabular}{lll}
\hline No & Indikator & Jumlah \\
\hline I. & $\begin{array}{l}\text { Pengelolaan Obat Dan } \\
\text { Bahan Medis Habis Pakai }\end{array}$ & $90 \%$ \\
2. & $\begin{array}{l}\text { Peralatan Dan Fasilitas } \\
\text { Pendukung }\end{array}$ & $87,5 \%$ \\
3. & $\begin{array}{l}\text { Pelayanan Informasi Obat } \\
\text { 4. }\end{array}$ & $100 \%$ \\
\hline Rata-Rata Nilai & $100 \%$ \\
\hline
\end{tabular}

Berdasarkan tabel 5 dari empat (4) indikator Pelayanan Kefarmasian di Puskesmas yang di gunakan dapat di Evaluasi Rata-Rata penerapan Pelayanan Kefarmasian di Puskesmas Tanjung Karang adalah baik sebesar 94,37\%.

Dalam setiap indikator pertanyaan yang terdapat dalam kuesioner di sesuaikan dengan tanggung jawab petugas farmasi, pengelolaan sediaan farmasi dan bahan medis habis pakai merupakan salah satu kegiatan pelayanan kefarmasian yang di mulai dari perencanaan, permintaan, penerimaan, penyimpanan, pendistribusian, pengendalian, pencatatan dan pelaporan serta pemantauan dan evaluasi.

Kegiatan pengelolaan obat dan bahan medis habis pakai terdapat IO (sepuluh) item pertanyaan, dan terdapat I pertanyaan yang menjawab TIDAK yang di mana item pertanyaan tersebut yaitu pendistribusian ke sub unit di lakukan dengan cara pemberian obat sesuai resep yang di terima. Tetapi puskesmas Tanjung Karang memakai buku permintaan obat sesuai dengan buku permintaan yang di terima dari masing-masing unit atau depo. Setelah di jumlahkan dengan rumus yang sudah di tentukan dimana presentase yang di peroleh yaitu 90\%.Dari tanggapan responden ini dapat di gambarkan bahwa kegiatan pengelolaan obat dan bahan medis habis pakai di Puskesmas Tanjung Karang sudah terlaksana sesuai dengan peraturan menteri kesehatan No 74 Tahun 2016 tentang standar pelayanan kefarmasian di puskesmas.

Pertanyaan yang berkaitan dengan peralatan dan fasilitas pendukung yang di perlukan untuk menunjang pelayanan kefarmasian di puskesmas Tanjung Karang dari I6 (Enam Belas) item pertanyaan terdapat 2 (dua) jawaban TIDAK yang di mana Puskesmas Tanjung Karang tidak memilki blanko salinan resep dan tidak memiliki ruang konseling untuk pasien dimana dengan presentase yang di peroleh $87,5 \%$, dan blanko salinan resep tidak di buat khusus karena resep di rekap menjadi satu dan resep kebanyakan di berikan I kali dan tidak memiliki ruang konseling pasien karena di Puskesmas Tanjung Karang ruangannnya hanya terbatas atau sempit, tetapi jika ada pasien yang membutuhkan konseling ,maka konseling akan di lakukan di dalam ruangan pelayanan Farmasi atau di sesuaikan.

Dari presentase yang di dapatkan dari hasil tanggapan responden tentang peralatan dan fasilitas pendukung yang ada di Puskesmas Tanjung Karang dapat di katakan baik namun Puskesmas Tanjung Karang tidak memiliki blanko salinan resep dan ruang konseling untuk pasien.

Pelayanan Informasi Obat merupakan kegiatan pelayanan yang di lakukan oleh Apoteker untuk memberikan informasi secara akurat, dan jelas. Dalam hal Pemberian Informasi Obat di Puskesmas Tanjung Karang dari 5 (Lima) item pertanyaan dan IOO responden semua pertanyaan jawaban YA yang di mana Puskesmas Tanjung Karang dalam Pelayanan Informasi obat sudah memberikan informasi mengenai jenis obat yang di berikan, cara pemakaian obat,( dosis obat, dan frekuensi, serta waktu penggunaan) dan efek samping obat serta bagaimana cara penyimpanan obat. 
Penyelenggaraan pelayanan kefarmasian di puskesmas minimal harus di laksanakan I orang Apoteker sebagai penanggung jawab, yang dpaat di bantu oleh Tenaga Teknis Kefarmasian sesuai kebutuhan dan ssemua tenaga Kefarmasian di puskesmas harus memiliki Surat Tanda Registrasi dan Surat Izin Praktik sesuai dengan ketentuan perundang-undangan.

Untuk Sumber Daya Manusia di puskesmas Tanjung Karang memiliki satu Tenaga Teknis Kefarmasian dan Apoteker Penanggung Jawab yang sudah memiliki Surat Tanda Registrasi dan Surat Izin Praktik.

Dari nilai Rata-rata $94,37 \%$ tentang penerapan standar pelayanan kefarmasian di puskesmas Tanjung Karang dapat di gambarkan bahwa pada dasarnya sudah dapat melaksanakan sesuai dengan peraturan menteri kesehatan No 74 Tahun 2016 tentang standar pelayanan kefarmasian di puskesmas.

\section{Simpulan dan Saran}

Penerapan standar pengelolaan obat dan bahan medis habis pakai di puskesmas Tanjung Karang dengan presentase sebesar 90\% (baik).

Penerapan standar Peralatan dan fasilitas pendukung yang ada di puskesmas Tanjung Karang dapat di katakan baik dan dari hasil tanggapan responden pada kuesioner masih ada yang belum terlaksana yaitu tidak memiliki blanko salinan resep dan ruang konseling untuk pasien. Dengan presentase yang di peroleh dari indikator peralatan dan fasilitas pendukung $87,5 \%$.

Penerapan standar pelayanan informasi obat di puskesmas Tanjung Karang dapat terlaksana dengan baik dengan presentase sebesar I00\%.

Penerapan standar Sumber daya manusia yang ada di Puskesmas Tanjung Karang dari 5 item pertanyaan sudah dapat terpenuhi dengan nilai presentase sebesar 100\%

\section{Daftar Pustaka}

Anonim, (1989), Metode Penelitian Survei, Pustaka LP3ES, Jakarta

Anonim, (2004), Keputusan Menteri Kesehatan Republik Indonesia Nomor 1027/MENKES/SK/X/2004 Tentang Standar Pelayanan Kefarmasian di Puskesmas, Departemen Kesehatan Republik Indonesia, Jakarta.

Anonim. (2006). Pedoman Pelayanan Kefarmasian di Puskesmas.

Anonim, (2009a), Undang-undangRepublik Indonesia Nomor 36 Tahun 2009 Tentang
Kesehatan ,PemerintahRepublik Indonesia, Jakarta.

Anonim, (2009b), Peraturan Pemerintah Nomor 5I Tahun 2009 Tentang Pekerjaan Kefarmasian, Departemen Kesehatan Republik Indonesia, Jakarta.

Anonim, (2009c), Peraturan Menteri Kesehatan Republik Indonesia Nomor 889/MENKES/PER/V/2009.

Departemen Kesehatan Republik Indonesia, Jakarta

Anonim, (20II), Peraturan Menteri Kesehatan Republik Indonesia Nomor376/MENKES/PER/V/20II,

Departemen Kesehatan Republik Indonesia, Jakarta.

Istiqomah,F.N, (2012) ,Evaluasi Implementasi Standar Pelayanan Kefarmasian Oleh Apoteker di Apotek Kabupaten Sleman, Skripsi, Fakultas Farmasi Universitas Gadjah Mada, Yogyakarta.

Notoatmodjo. (20I4). Metodologi Penelitian. Yogyakarta: Rineka Cipta.

Peraturan Menteri Kesehatan RI. 2016 No. 74. Tentang Standar Pelayanan Kefarmasian di Puskesmas

Puput Widha dkk, (2015), Gambaran penerapan standar pelayanan kefarmasian $\mathrm{x}$ kota magelang: magelang

Peraturan Menteri Kesehatan 2016 No. 74 Tentang Standar pelayanan Kefarmasian di Puskesmas

Sugiyono, (2009), Statistik Untuk Penellitian, Alfabeta, Bandung. 